\title{
The Crowdfunding: A New Financial Instrument for the Start-Ups?
}

\author{
Marina Damilano ${ }^{1} \&$ Cristina Rovera ${ }^{1}$ \\ ${ }^{1}$ Respectively Full and Associate Professor of the Management Department, University of Turin, Italy \\ Correspondence: Prof. Cristina Rovera, Management Department, University of Turin, Italy. E-mail: \\ cristina.rovera@unito.it
}

Received: July 27, 2018

doi:10.5539/ijbm.v13n11p199
Accepted: September 19, 2018

URL: https://doi.org/10.5539/ijbm.v13n11p199

Online Published: October 12, 2018

\begin{abstract}
Start-ups are new businesses, which need a good amount of equity to finance investments. Crowdfunding is an alternative instrument to collect money. It does not need the intervention of a bank, but allows to obtain the funds directly from the public by network platforms.

This article focuses on the possibility for a start-up to raise capital through crowdfunding. The argument is quite known on an international level, even if scholars often focus on specific problems or on particular moments of the life cycle of the start-up. On the contrary, the two arguments are really new in Italy. The Italian crowdfunding market is young - the main increase in the platforms number $(+63 \%)$ is between 2013 and 2014 - and the national regulation which allows to finance start-ups by crowdfunding is even more recent (latest legal document in 2017).

The novelty of the topic explains the added value of this article. To the best of our knowledge, no previous study focused on the Italian start-ups financed by crowdfunding. We analyze the phenomenon from the birth of the different platforms (2005 for the first one) since the end of the first semester 2018.
\end{abstract}

Keywords: Start-up - Equity crowdfunding - Lending crowdfunding

\section{Introduction}

Our interest for the subject has been sparked by its novelty. Innovative start-ups and crowdfunding are young themes, especially in terms of national legislation. Given the difficulty faced by innovative businesses in raising funds, and the origins of Italian crowdfunding, we have identified the system as a new form of financing. The main increase in the number of the Italian platforms is $+63 \%$ and it has been registered between 2013 and 2014. Italian regulation about equity crowdfunding is even more recent: the date of the latest legal document is June 2017. In Italy the field is still at the infant level, but - given the development opportunities demonstrated in the international context - it certainly shows excellent growth potential.

The theme has been analyzed more in depth at the international level, but scholars often focus on specific problems or to particular moments of the life cycle of the start-up. On the contrary, we look both to the birth and to the total life of a start-up, which needs a suitable amount of equity to launch and develop new businesses. Finally, we cannot forget that successfull start-ups usually develop outside the country of origin. The argument is therefore interesting both for Italian entrepreneurs and for international commerce.

The phenomenon is studied from the birth of the Italian platforms (2005 for the first one, named Produzioni dal Basso) since the end of the first semester 2018. Starting from Produzioni dal Basso, we consider an historical period of 13 years, but - considering that most platforms were born in 2014 - we have a panel of 4 years. After the introduction (paragraph 1), the literature and method (paragraph 2), we present the main and most interesting information in paragraphs 3 and 4, which offer a detailed description of the Italian start-ups and crowdfunding markets. Paragraph 5 concludes, reflecting about the better resources for the Italian start-ups.

\section{Literature and Method}

\subsection{Literature}

The most relevant start-up literature includes - on an international level - Berger and Udell (1998), Cassar (2004), Nanda and Rhodes-Kropf, and - on a national level - Nadotti (2014), Bartolomei and Marcozzi (2015), Pagamici (2015), Brusa (2016), and Chioda (2016). 
Crowdfunding is a topic abundantly dealt on an international scale: Schwienbacher and Larralde (2010), Agrawal et al. (2011), Joachim (2011), Ley and Weaven (2011), Lawton and Marom (2013), Coocheo (2013), Kim et al. (2013), Sannajust et al. (2014), Borello et al. (2014), Belleflamme et al. (2014), Mollick (2014), Kuppuswamy and Bayus (2015), Massolution (2015), Costanza (2017), Paschen (2017), Di Pietro, Prencipe and Majchrzak (2018).

Considering studies on crowdfunding in Italy, the situation is completely different. The argument is new and we make reference to:

- $\quad$ Current legislation, based on European documents (ESMA 2012, EC 2014, EBA 2015) and national legal texts (D.L. 179/2012, L. 221/2012, CONSOB Rule 18592/2013, D.L. 3/2015, L. 33/2015, CONSOB Deliberation 19520/2016, L. 232/2016, D.L. 50/2017 and L. 96/2017);

- The most important scientific articles, including Giudici et al. (2012), Piattelli (2013), Ruozi (2014), Previati et al. (2014), Querci (2014), Università Cattolica del Sacro Cuore (2015), Rovera (2016) and Politecnico di Milano (2016, 2017, 2018). Certain texts are focused on specific subtopics (e.g. the comparison with credit crunch), while others present the system as a whole (observatory reports).

While on international level the studies of Ley and Weaven, Costanza, Paschen, Di Pietro, Prencipe and Majchrzak are focused on both start-ups and crowdfunding (even if to solve some specific life cycle problems), in Italy the two sectors are not exhaustingly treated together.

\subsection{Method}

Our work has consisted in an accurate update of the information collected about Italian start-ups and crowdfunding. Our research has included the collection of written literature and online literature, as well as interviews to professionals.

To study crowdfunding, we analyzed observatory reports and connected to the network. The objective was to verify the actual existence and functioning of the portals, as well as the presence of descriptive documents about regulation. The written and online literature has been completed by the participation to specific conferences, which gave us the opportunity to develop contacts and interviews (Note 1).

The analysis proposed is focused on the total number of Italian start-ups and on the total number of Italian crowdfunding portals. As far as possible we gave the cases a uniform treatment.

\section{Start-Ups and the Capital Market}

Today, the term "start-up" - initially created to identify new companies launched in the IT and new technology sectors - is applied on a wider scale and includes all new businesses, independent of their sector of pertinence (Brusa, 2016).

Easily accessible official data related to the size of the start-up industry in our country only include innovative start-ups registered in the specific section of the Italian company register, in accordance with Italian Decree-Law $n^{\circ} 179 / 2012$ named Decree for Growth 2.0 (Note 2).

On the basis of the aforementioned data, Table 1 provides a snapshot of the system of "profit-oriented" start-ups present in Italy.

Table 1. Italian start-ups by market sector

\begin{tabular}{lll}
\hline Sector & $\mathbf{N}^{\circ}$ of start-ups & $\mathbf{\%}$ \\
\hline Agriculture and related activities & 58 & $0.65 \%$ \\
Manufacturing, energy, and mining & 1,692 & $19.02 \%$ \\
Construction & 99 & $1.11 \%$ \\
Sales & 363 & $4.08 \%$ \\
Tourism & 57 & $0.64 \%$ \\
Transportation and delivery & 28 & $0.31 \%$ \\
Insurance and credit & 14 & $0.16 \%$ \\
Corporate services & 6,347 & $71.34 \%$ \\
Other sectors & 214 & $2.41 \%$ \\
Non classifiable & 25 & $0.28 \%$ \\
Total & $\mathbf{8 , 8 9 7}$ & $\mathbf{1 0 0 . 0 0 \%}$ \\
\hline
\end{tabular}

Source: Italian company registry, Innovative start-ups, $1^{\text {st }}$ trimester 2018 
Table 2 offers the geographic distribution of the Italian start-ups, showing that Lombardy holds the first place (24\%), followed by Lazio and Emilia-Romagna (10\%), Veneto (9\%), Campania (7\%) and Piedmont (5\%).

Table 2. Italian start-ups: regional distribution

\begin{tabular}{llll}
\hline Rank & Region & $\mathbf{N}^{\circ}$ of start-ups & $\mathbf{\%}$ \\
\hline 1 & Lombardy & 2,132 & $23.96 \%$ \\
2 & Lazio & 911 & $10.24 \%$ \\
3 & Emilia-Romagna & 884 & $9.94 \%$ \\
4 & Veneto & 822 & $9.24 \%$ \\
5 & Campania & 658 & $7.40 \%$ \\
6 & Piedmont & 472 & $5.31 \%$ \\
7 & Sicily & 460 & $5.17 \%$ \\
8 & Tuscany & 392 & $4.41 \%$ \\
9 & Marche & 366 & $4.11 \%$ \\
10 & Apulia & 337 & $3.79 \%$ \\
11 & Trentino-South Tyrol & 230 & $2.59 \%$ \\
12 & Abruzzi & 214 & $2.41 \%$ \\
13 & Friuli-Venezia Giulia & 205 & $2.30 \%$ \\
14 & Calabria & 190 & $2.14 \%$ \\
15 & Sardinia & 165 & $1.85 \%$ \\
16 & Liguria & 165 & $1.85 \%$ \\
17 & Umbria & 153 & $1.72 \%$ \\
18 & Basilicata & 82 & $0.92 \%$ \\
19 & Molise & 41 & $0.46 \%$ \\
20 & Aosta Valley & 18 & $0.20 \%$ \\
& Total & $\mathbf{8 , 8 9 7}$ & $\mathbf{1 0 0 . 0 0 \%}$ \\
& Average number per region & $\mathbf{4 4 5}$ & $\mathbf{5 . 0 0 \%}$ \\
\hline
\end{tabular}

Source: Italian company registry, Innovative start-ups, $1^{\text {st }}$ trimester 2018.

Disaggregating the analysis to the city district level, Milan features 1,494 start-ups, immediately followed by Rome (798) and Turin (322) (see Table 3).

Table 3. Italian start-ups: city district distribution - ranking of top-10 cities

\begin{tabular}{llll}
\hline Rank & City district & No of start-ups & $\begin{array}{c}\text { of national } \\
\text { start-up total }\end{array}$ \\
\hline 1 & & & $16.79 \%$ \\
2 & Milan & 1,494 & $8.97 \%$ \\
3 & Rome & 798 & $3.62 \%$ \\
4 & Turin & 322 & $3.26 \%$ \\
5 & Naples & 290 & $3.20 \%$ \\
6 & Bologna & 285 & $2.54 \%$ \\
7 & Padua & 226 & $1.93 \%$ \\
8 & Bari & 172 & $1.80 \%$ \\
9 & Salerno & 160 & $1.79 \%$ \\
10 & Modena & 159 & $1.73 \%$ \\
\hline
\end{tabular}

Source: Italian company registry, Innovative start-ups, $1^{\text {st }}$ trimester 2018.

Once again, the statistics processed by the Company Registry highlight a significant indicator of the issue that all start-ups face: the obtainment of funds necessary for their launch.

The financial independence indicator for innovative start-ups, calculated as a ratio of assets funded through equity, appears to be slightly lower than the indicator for all joint-stock companies ( 0.31 versus $0.40,2016$ data) (Note 3 ). The slight difference in value - moreover a negative value - contrasts with the thesis hypothesized by 
supporters of the so-called "financial growth cycle" (Berger and Udell, 1998), according to whom the optimal financial structure of a company depends on the degree of development reached. In particular, the sources available to a start-up (an innovative start-up in particular) follow a financial hierarchy which establishes that funding in the form of equity must have the priority over resort to bank indebtedness. The first is less expensive and more suitable for the purpose. In fact, a suitable equity allows, on one hand, the start-up to convince potential investors on the reliability of the business launch through direct involvement of the business team, and on the other hand to guarantee a degree of management and operational elasticity, maintaining the finance capacity necessary for the following phases of business growth and development (Nadotti, 2014).

Nevertheless, an empirical assessment - at least of the Italian situation - shows how start-ups greatly struggle to collect a suitable amount of equity. Indeed the aforementioned data highlights how innovative start-ups have a structure much like existing joint-stock companies, which by nature rely mainly upon debt.

The above-recorded data in fact highlights that the financial structure of innovative start-ups is quite similar to that of existing joint-stock companies, which by nature rely mainly on debt capital. The peculiarity of the Italian situation may be explained by the opportunity - offered by the Decree for Growth 2.0 to innovative start-ups (as they are defined by the legislation) - to have a simplified, free, and direct access to the FGPMI (guarantee fund for SMEs) (Note 4). By doing this, though, lawmakers have favoured the development of a leverage-based Italian start-up system (Econopoly, 2017), with all the related criticalities that such type of financial structure implies for business initiatives in their launch phase.

At this stage, though, a question comes to mind: what are the sources that a start-up should use to launch their new business and maintain a solid financial base? In a nutshell, following the aforementioned financial growth cycle approach, funding sources for start-ups are summarized in Table 4 below.

Table 4. Firm continuum and sources of finance

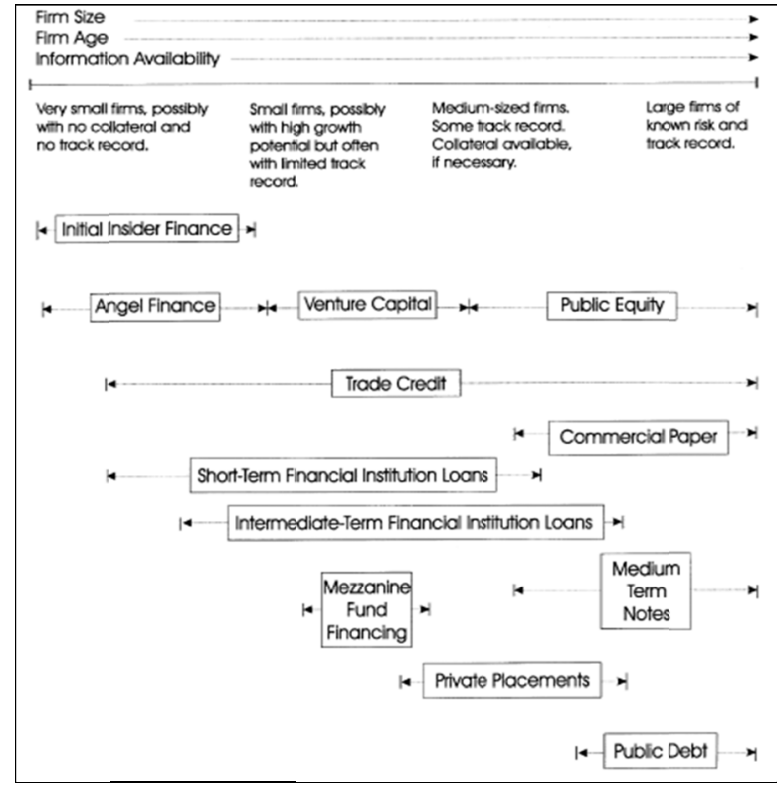

Source: Berger, Udell, Journal of Banking \& Finance, 22 (1998), pg. 623.

Nonetheless, the above diagram, published in 1998, does not take into account a new and growingly important source of funding: crowdfunding on Internet platforms.

The aim of this article is to complete the framework with a close examination of the opportunities offered by this new form of online funding.

\section{Crowdfunding: Definition, History and Models}

Crowdfunding is a funding tool that may be accessed by individuals, SMEs, non-profit organizations, and innovative start-ups, which allows to raise funds from individuals or groups to finance projects, whether reward based or not. 
Contact with investors occurs through an online platform, which excludes traditional banking intermediation. Subjects involved may be classified in two categories as follows:

- $\quad$ Creators or borrowers, who ask and receive funds from the public;

- $\quad$ Crowdfunders: natural or legal persons lending funds.

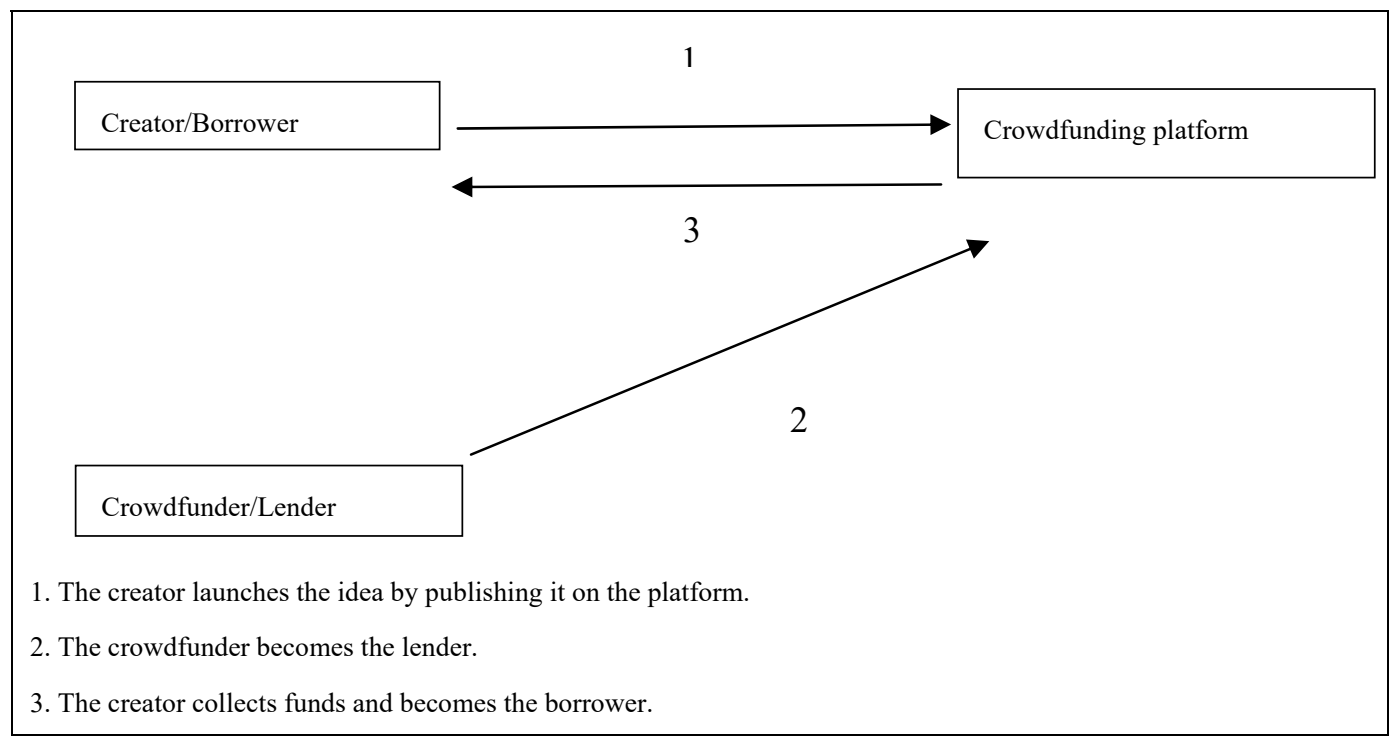

Figure 1. Subjects involved (Note 5)

On an international level, the first relevant experiment dates back to the late 1800 s, when the U.S. magazine The World used it for the erection of the Statue of Liberty. In 2008 Barack Obama used the tool to fund his election campaign.

The start of Italian crowdfunding history may instead be considered 2005, when Angelo Rindone (professional web consultant) founded the platform "Produzioni dal Basso". The main increase was registered in 2013-2014, during which the number of the platforms grew by $63 \%$. Starting from the birth of Produzioni dal Basso, we consider an historical period of 13 years, but - considering that most platforms were born in 2014 - we have a panel of 4 years.

There are essentially four types of crowdfunding (see Table 5): donation, reward, equity, and lending. In donation crowdfunding, participation is not reward-based; it is a donation in favour of the promoter of the initiative. In reward crowdfunding, the funder receives a non-monetary reward, such as a gadget, a discount, or a trial sample of the project sustained. Equity crowdfunding involves share-based participation, and gives the funder both equity and administration powers. When rewards are provided in the form of interest, crowdfunding is called lending crowdfunding (Note 6), with funds being an alternative to bank indebtedness and/or bonded debt. Further categories exist, created as hybrid models or developed as a supplement to the ones listed below (Note 7).

Table 5. Crowdfunding types

\begin{tabular}{ll}
\hline Type & Characteristics \\
\hline Donation & Non reward-based participation \\
Reward & Non-monetary reward-based (gadget, product, or discount) \\
Equity & Share-based participation \\
Lending & Rewards provided in the form of interest \\
\hline
\end{tabular}

The majority of Italian platforms are reward-based, though the greatest sums in 2015 were collected through hybrid types, including reward+donation and donation+debt $(+23.8$ million Euros). If one considers that the total sum collected amounted to 23 million Euros in 2013, 31 million Euros in 2014, and 56.8 million Euros in 2015, the values highlight a positive trend equal to $+35 \%$ and $+83 \%$. 
The project success rate is about $30 \%$, given that the use of funds collected may be either dependent or independent of reaching certain goals (all-or-nothing as opposed to keep-it-all). Considering the crowdfunding most accessible by national start-ups, the remainder of the article shall focus on equity and lending crowdfunding.

\subsection{Crowdfunding Regulations}

Italy is among EU countries with most legislation on the matter, though limited to equity crowdfunding. The main references are the 2012/557 ESMA document (Investor warning about online investments); the March $27^{\text {th }} 2014$ EC notice and the EBA Opinion issued on February $26^{\text {th }} 2015$. The documents lay out the essential traits of crowdfunding, highlighting the sources of risk and the related reparatory directives (PSD 2007/64/EC).

Equity crowdfunding in Italy was initially designed for innovative start-ups, under the legislation of Decree-Law $\mathrm{n}^{\circ} 179$ issued on October 2012, later amended as Law $\mathrm{n}^{\circ} 221$ issued on December $17^{\text {th }} 2012$. Detailing of the legislation was assigned to CONSOB (Note 8), which published Regulations n ${ }^{\circ} 18592$ on June $26^{\text {th }} 2013$.

The aforementioned regulations establish guidelines for management of platforms, reserved to banks, joint-stock companies, and individuals authorized by CONSOB. In fact, the commission holds a specific registry, subdivided in two categories: ordinary and special. The first category includes the list of companies authorized by CONSOB, while the second category includes the banks and brokerage firms directly authorized by the central bank of Italy. To grant access to the ordinary category, CONSOB verifies the following prerequisites:

- $\quad$ The joint-stock company structure;

- The respectability and professionality of stockholders and administrators;

- The existence of a report concerning the corporate activity and structure.

Periodic verification of registry members occurs through request of information and documents, as well as inspections. Breaches are punished with fines or through suspension or cancellation from the registry.

Moreover, the CONSOB Regulations establish the disclosure standards undertaken by the platform, allowing users to make conscious investment decisions. Funding requests must not exceed 5 million Euros, and $5 \%$ of the total must be undersigned by professional investors (banks, insurance companies, foundations, investment funds, pension funds), who increase the reliability of the projects. Before subscribing the online proposals, retail investors must complete an informed path, stating to have understood the characteristics and risks related to innovative start-ups and to be able to sustain eventual financial losses. Small investors are always recognized the right to unmotivated withdrawal without financial loss, exercisable within 7 days from the date of subscription. Withdrawal is also justified in the eventuality of changes or corrections to the information initially provided, or in case of transfer of share ownership.

Decree-Law $n^{\circ} 3$ issued on January $24^{\text {th }} 2015$ - amended as Law $n^{\circ} 33$ issued on March $24^{\text {th }} 2015$ - has introduced the first change to the regulations, extending the use of equity crowdfunding to innovative SMEs, to UCIs, and other joint-stock companies investing in start-ups or innovative SMEs. The innovative SMEs are joint-stock companies, not listed on any regulated market, and with their latest certified financial statements published in Italy and latest fiscal residence in Italy. They share at least two of the three innovation requirements of start-ups, but have lower thresholds in terms of size and quality standards. CONSOB has thus revised the 2013 Regulations $\mathrm{n}^{\circ} 19520$ approved on February $24^{\text {th }} 2016$, introducing the following fundamental changes:

- Serial investors (including business angels, Note 9) must purchase at least $5 \%$ of the capital required, facilitating the fulfilment of the restrictions;

- Platform activity must begin within 6 months of the authorization, otherwise it shall be considered void.

The major change has instead come into effect with Law $n^{\circ} 232$ issued on December $11^{\text {th }} 2016$, which has extended the use of equity crowdfunding to all SMEs registered as joint-stock companies. Nevertheless, upon drafting the document, the legislator has committed certain formal omissions, including the application of the provision to innovative start-ups and SMEs registered as limited companies. The omission was corrected by means of Decree-Law n ${ }^{\circ} 50$ (the so-called Corrective Decree) issued on April $24^{\text {th }} 2017$, amended as Law $n^{\circ} 96$ issued on June $21^{\text {st }} 2017$.

Currently equity crowdfunding is therefore a type of crowdfunding accessible by both innovative start-ups and SMEs, registered in any form.

\subsection{Equity Crowdfunding}

Observatories show that, as at the first semester of 2018, 27 equity crowdfunding platforms exist in Italy: 25 
registered in the ordinary category, and 2 registered in the special category (see Table 6).

Table 6. Equity platforms

\begin{tabular}{|c|c|c|}
\hline Website & Controlling company & Date of authorization \\
\hline Unicaseed.it & Unica SIM & Special category \\
\hline Tifosy.com & Tifosy Limited & Special category \\
\hline Starsup.it & Starsup Srl & $18 / 10 / 2013$ \\
\hline Actioncrowd.it & Action crowd $\mathrm{Srl}$ & $26 / 2 / 2014$ \\
\hline 200crowd.com & The Ing Project Srl & $18 / 6 / 2014$ \\
\hline Nextequity.it & Next equity crowdfunding marche $\mathrm{Srl}$ & $16 / 7 / 2014$ \\
\hline Crowdfundme.it & Crowdfundme Srl & $30 / 7 / 2014$ \\
\hline Muumlab.com & Muum lab Srl & $6 / 8 / 2014$ \\
\hline Mamacrowd.com & Siamosoci Srl & $6 / 8 / 2014$ \\
\hline Fundera.it & Fundera Srl & $10 / 9 / 2014$ \\
\hline Ecomill.it & Ecomill Srl & $29 / 10 / 2014$ \\
\hline Wearestarting.it & Wearestarting Srl & $16 / 12 / 2014$ \\
\hline Backtowork24.com & Backtowork24 Srl & $14 / 1 / 2015$ \\
\hline Investi-re.it & Baldi Finance SpA & $28 / 1 / 2015$ \\
\hline Crowd4capital.it & Roma Venture Consulting Srl & $8 / 10 / 2015$ \\
\hline Opstart.it & Opstart Srl & $11 / 11 / 2015$ \\
\hline Cofyp.com & Cofyp Srl & $14 / 4 / 2016$ \\
\hline Clubdealonline.com & Clubdeal Srl & $8 / 3 / 2017$ \\
\hline Walliance.eu & Walliance Srl & $30 / 3 / 2017$ \\
\hline Europacrowd.it & Europa HD Srl & $7 / 6 / 2017$ \\
\hline Italyfunding.com & Italyfunding Srl & $6 / 9 / 2017$ \\
\hline Ideacrowdfunding.it & Idea Crowdfunding $\mathrm{Srl}$ & $29 / 11 / 2017$ \\
\hline Thebestequity.com & Gamga Srl & $14 / 3 / 2018$ \\
\hline Leonardoequity.com & Management Capital Partner Srl & $17 / 4 / 2018$ \\
\hline Concreteinvesting.com & Concrete Srl & $24 / 4 / 2018$ \\
\hline It.lita.com & 1001Pact Italy Srl & $31 / 5 / 2018$ \\
\hline Lifeseeder.com & Lifeseeder SpA & $28 / 6 / 2018$ \\
\hline
\end{tabular}

Total figures related to the project funding campaigns are shown on Table 7. Collected funds only refer to successfully concluded initiatives at $30^{\text {th }}$ June 218. It is interesting to notice the existence of platforms which though established in the 2014-2015 biennium - have yet to publish projects (see: Fundera, Ecomill, and Crowd4capital), while others (Tifosy, Italyfunding, Ideacrowdfunding, Ideacrowdfunding, Thebestequity, Leonardoequity, Concreteinvesting, It.lita.com and Lifeseeder) are either too young (born at the end of 2017 or at the beginning of 2018) or have presented initiatives difficult to relate to the traditional crowdfunding market. The latter refer to, for example, Clubdealonline, whose projects are not publically accessible as it requires membership-type participation. 
Table 7. Project campaigns and funds

\begin{tabular}{lllll}
\hline Platform & CONSOB Category & Project campaigns & Funds (Euros) & Success rate (\%) \\
\hline Unicaseed.it & special & 4 & 158,000 & $25 \%$ \\
Starsup.it & ordinary & 31 & $3,538,000$ & $43 \%$ \\
Actioncrowd.com & ordinary & 5 & 928,000 & $40 \%$ \\
Nextequity.it & ordinary & 8 & $1,453,000$ & $40 \%$ \\
Crowdfundme.it & ordinary & 47 & $6,859,000$ & $72 \%$ \\
200 Crowd & ordinary & 17 & $2,261,000$ & $79 \%$ \\
Investi-re & ordinary & 2 & 117,000 & $50 \%$ \\
Wearestarting & ordinary & 15 & 719,000 & $54 \%$ \\
Backtowork24 & ordinary & 16 & $1,433,000$ & $73 \%$ \\
Opstart & ordinary & 33 & $3,580,000$ & $86 \%$ \\
Muumlab.com & ordinary & 4 & 100,000 & $50 \%$ \\
Mamacrowd.com & ordinary & 38 & $9,305,000$ & $90 \%$ \\
Cofyp & ordinary & 1 & 214,000 & $100 \%$ \\
Walliance.eu & ordinary & 4 & $2,390,000$ & $100 \%$ \\
\hline
\end{tabular}

The data on Table 7 is encouraging, especially in comparison to past data. Project funding campaigns have increased by 106\% compared to 2017 (225 versus 109), and funds have increased by 175\% (33 versus 12 million Euros). The greatest capital was obtained through Mamacrowd (9 million Euros), with 3:8 active proposals and a $90 \%$ success rate. Success rates in general are encouraging. The top-ranked platforms in this field are Walliance and Cofyp (100\%), followed by Mamacrowd (90\%), Opstart (86\%) and 200 Crowd (79\%). Walliance is the first Italian equity platform focused on real estate. It is considered in Table 7, but it is then excluded for the particular nature of its activity.

Close analysis must be nonetheless made of the number of projects published. Cofyp presented a single proposal, which is not representative of true absolute efficiency. In comparison, the result shown by Crowdfundme, which obtained positive results for 47 project campaigns, is much more significant. The least efficient platform is Unicaseed, registered in the special category, which only recorded a $25 \%$ success rate over 4 different initiatives.

The topic is more closely analysed in Figure 2, which shows a comparison across time. The 2018 value is partial, as 31 project funding campaigns are still not concluded, but the graph nonetheless shows a certainly positive trend. Upon assessment of absolute values as opposed to percentage values, successful initiatives show a $92 \%$ Cagr (Note 10) between 2014 and 2018.

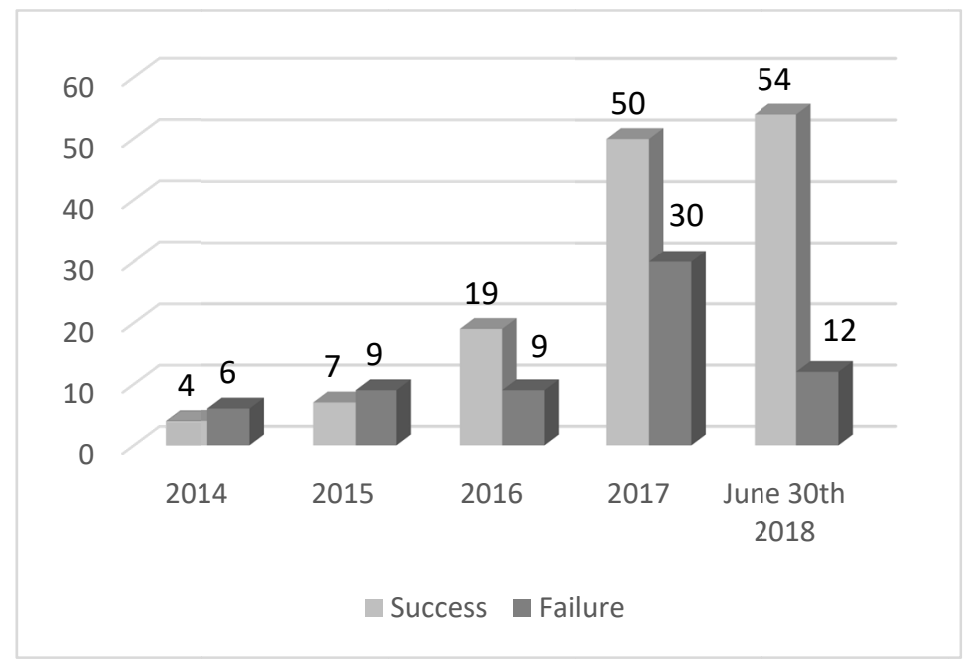

Figure 2. Project campaign results

Table 8 and Figure 3 show the characteristics of the projects presented to the public. On average, target funds have decreased throughout the years, with the exception of 2015, when the request exceeded 400,000 Euros. The maximum value reaches 1.5 million Euros, while the minimum value recorded is 37,500 Euros at $30^{\text {th }}$ June 2018. 
Coherently with the trend recorded for target funds, the percentage of funds offered also shows a negative trend: $27 \%$ in $2014,8.6 \%$ in 2018 . The maximum value was reached in 2017 , with the percentage of $99 \%$, while the minimum value is recorded in 2018 , with $0.17 \%$ being offered. An interesting change occurred in terms of minimum investment allowed. In 2016, 2017 and 2018 most investors (65\%, 59\% and 51\% respectively) offered between 101 and 500 Euros, but whilst in 2016 19\% of funders preferred to invest less than 100 Euros, in $2017 / 2018$ the $24 \%$ - $35 \%$ of them were willing to invest between 501 and 1,000 Euros. Finally, the bottom part of the table shows the funding objectives. Since multiple answers were allowed, the total amount exceeds $100 \%$. $59 \%$ of capital is allocated to marketing expenses, $37 \%$ to the platforms development, $34 \%$ to $\mathrm{R} \& \mathrm{D}, 32 \%$ to geographic expansion, and $26 \%$ to employment.

Table 8. Projects presented

\begin{tabular}{|c|c|c|c|}
\hline \multicolumn{4}{|l|}{ Target funds (Euros) } \\
\hline Year & Minimum value & Maximum value & Average value \\
\hline 2014 & 99,200 & 636,000 & 284,745 \\
\hline 2015 & 80,000 & $1,000,227$ & 421,201 \\
\hline 2016 & 50,000 & 720,000 & 209,551 \\
\hline 2017 & 40,000 & $1,507,908$ & 177,496 \\
\hline June $30^{\text {th }} 2018$ & 37,500 & 100,000 & 203,168 \\
\hline \multicolumn{4}{|c|}{ Percentage of funds offered } \\
\hline Year & Minimum value & Maximum value & Average value \\
\hline 2014 & $5.10 \%$ & $86.70 \%$ & $27.00 \%$ \\
\hline 2015 & $5.00 \%$ & $45.40 \%$ & $19.50 \%$ \\
\hline 2016 & $1.70 \%$ & $43.80 \%$ & $18.20 \%$ \\
\hline 2017 & $0.20 \%$ & $99.00 \%$ & $12.20 \%$ \\
\hline June $30^{\text {th }} 2018$ & $0.17 \%$ & $98.8 \%$ & $8.6 \%$ \\
\hline \multicolumn{4}{|c|}{ Minimum investment allowed } \\
\hline Sum & June 2016 & June 2017 & June 2018 \\
\hline$\leq 100$ Euros & $19 \%$ & $7 \%$ & $4 \%$ \\
\hline $101-500$ Euros & $65 \%$ & $59 \%$ & $51 \%$ \\
\hline $501-1,000$ Euros & $2 \%$ & $24 \%$ & $35 \%$ \\
\hline$>1,000$ Euros & $14 \%$ & $10 \%$ & $10 \%$ \\
\hline Total & $100 \%$ & $100 \%$ & $100 \%$ \\
\hline \multicolumn{4}{|l|}{ Allocation of funds } \\
\hline Main objectives & & Allocation (\%) & \\
\hline Marketing & & $59 \%$ & \\
\hline Platform development & & $37 \%$ & \\
\hline $\mathrm{R} \& \mathrm{D}$, innovation & & $34 \%$ & \\
\hline Market expansion & & $32 \%$ & \\
\hline Employment & & $26 \%$ & \\
\hline Geographic expansion & & $23 \%$ & \\
\hline General expenses & & $19 \%$ & \\
\hline Market consolidation & & $12 \%$ & \\
\hline Other (no detail) & & $6 \%$ & \\
\hline
\end{tabular}

Figure 3 describes the projects in terms of shares held conveying voting rights to crowdfunders: with voting rights, without voting rights, and hybrid. Most shares convey hybrid rights (48\%), which only allow main investors to have voting power, followed by voting rights $(37 \%)$ and not voting rights $(11 \%)$. The Other category (4\%) refers to shares conveying voting rights, but rights different to those normally conveyed (either in terms of privileges or of limitations). 


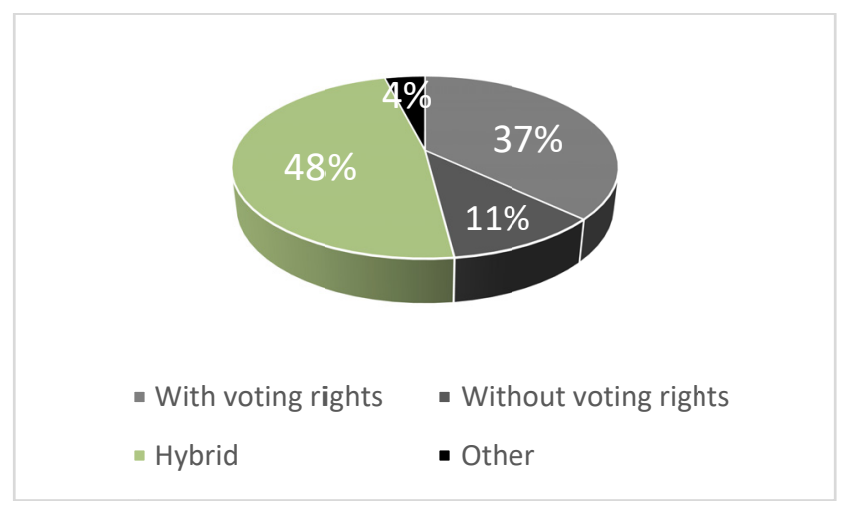

Figure 3. Shares held conveying voting rights

Table 9 presents the data related to project launchers, of which $85 \%$ consists of innovative start-ups. Although the total number of project campaigns is 225 , the amount of launchers is 214 , because certain companies have launched more than one initiative, either on the same platform or different platforms.

The table also describes the economic and equity status of the launchers. In terms of turnover, the average value settles around 478,000 Euros, while the maximum value exceeds 47 million Euros. The minimum declared value is instead 0 Euros, in line with the age of the specific company, which may be either just born or very recently established (the average age is 2 years, with 7 shareholders). The information related to net equity must be read in parallel with that related to turnover. If the turnover is zero, net equity fall sub-zero, since the capital and (limited) reserves are crushed by the operating loss. The table concludes with the pre-money valuation of the launcher: such valuation quantifies its value, the expected capital increase, and the shareholding percentage proposed (Note 11). 54\% of start-ups are worth between 1 and 5 million Euros, while 27\% are worth between 500,000 and 1 million Euros, and 11\% between 100,000 and 500,000 Euros. Only 1\% are worth more than 10 million Euros.

Table 9. Project launchers

\begin{tabular}{|c|c|c|c|}
\hline Type & \multicolumn{2}{|l|}{ Amount } & In $\%$ \\
\hline Innovative start-ups & \multicolumn{2}{|l|}{181} & $85 \%$ \\
\hline Innovative SMEs & \multicolumn{2}{|l|}{18} & $8 \%$ \\
\hline Standard SMEs & \multicolumn{2}{|l|}{11} & $2 \%$ \\
\hline Investment vehicles & \multicolumn{2}{|l|}{4} & $5 \%$ \\
\hline Total & \multicolumn{2}{|l|}{214} & $100 \%$ \\
\hline \multicolumn{4}{|l|}{ Financial information } \\
\hline Information & Minimum value & Maximum value & Average value \\
\hline Turnover as at latest financial statements (Euros) & 0 & $47,841,831$ & 477,762 \\
\hline Net equity before campaign (Euros) & $(555,372)$ & $5,341,888$ & 159,372 \\
\hline Profit as at latest financial statements (Euros) & $(3,115,804)$ & $1,225,824$ & $(43,617)$ \\
\hline Company age (years) & 0 & 30 & 2.4 \\
\hline $\mathrm{N}^{\circ}$ of shareholders before campaign & 1 & 79 & 6.5 \\
\hline Pre-money valuation (Euros) & 10,000 & $31,194,240$ & $2,183,455$ \\
\hline \multicolumn{4}{|l|}{ Detail: Pre-money valuation } \\
\hline Value & \multicolumn{2}{|l|}{ Amount } & In $\%$ \\
\hline$\leq 100,000$ Euros & \multicolumn{2}{|l|}{2} & $1 \%$ \\
\hline 100,001 - 500,000 Euros & \multicolumn{2}{|l|}{23} & $11 \%$ \\
\hline $500,001-1,000,000$ Euros & \multicolumn{2}{|l|}{55} & $27 \%$ \\
\hline $1,000,001-5,000,000$ Euros & \multicolumn{2}{|l|}{111} & $54 \%$ \\
\hline $5,000,001-10,000,000$ Euros & \multicolumn{2}{|l|}{12} & $6 \%$ \\
\hline$>10,000,000$ Euros & \multicolumn{2}{|l|}{3} & $1 \%$ \\
\hline Total & \multicolumn{2}{|l|}{206} & $100 \%$ \\
\hline
\end{tabular}




\subsection{Lending Crowdfunding}

The first-ever crowdfunding operators in Italy once worked as intermediaries in accordance with Article 106 of the Italian banking act (Note 12). Their legal framework is Decree-Law $n^{\circ} 11 / 2010$, in implementation of the PSD 2007/64/EC, which - along with Resolution $n^{\circ} 584 / 2016$ issued by the central bank of Italy - defined them as Payment Institutions.

Table 10 provides the list of existent platforms (a total of 10) as at the end of June 2018, distinguishing them in function of the target user, which may be either consumer or business.

Table 10. Lending platforms

\begin{tabular}{lll}
\hline Website & Controlling company & Target \\
\hline BLender.loans & BLender Global /Lemon Way SA & Consumer \\
Motusquo.it & Motusquo.it/ Lemon Way SA & Consumer \\
Prestiamoci.it & Prestiamoci SpA/ Pitupay SpA & Consumer \\
Smartika.it & Smartika SpA & Consumer \\
Soisy.it & Soisy SpA & Consumer \\
BorsadelCredito.it & Business InnovationLab SpA / Mo.Net SpA & Business \\
It.lendix.com & Lendix Italia Srl /Lendix SA & Business \\
TheSocialLender.it & The Social Lender Srl / Lemon Way SA & Business \\
Terzovalore.com & Banca Prossima & Non-profit organization \\
Housers.com & Housers Global Properties PFP / Lemon Way SA & Real estate \\
\hline
\end{tabular}

Coherently with the scope of the article, we shall focus only on pure business-targeted platforms: BorsadelCredito, Lendix, and TheSocialLender. Table 11 highlights the requirements that the applicant must satisfy, which vary from platform to platform. While requirements by Borsadel Credito are outlined in detail, Lendix and TheSocialLender requirements are more generic, as the assessment is allocated to an internal commission. For Lendix this is due to the internationalization of the platform, born in France but recently expanded to Spain and Italy. TheSocialLender, on the contrary, is a new entry in the Italian market; born in November 2017.

Table 11. Applicant requirements

\begin{tabular}{|c|c|c|c|}
\hline Requirements & BorsadelCredito & Lendix & The SocialLender \\
\hline \multirow{7}{*}{ For the applicant } & The company must: & \multirow{7}{*}{$\begin{array}{l}\text { The financial, profitability and } \\
\text { management requirements are } \\
\text { assessed by an internal } \\
\text { commission, which shall assign } \\
\text { a rating from } \mathrm{A}+\text { to } \mathrm{C}\end{array}$} & \multirow{4}{*}{$\begin{array}{l}\text { Direct model: } \\
\text { the lender can independently } \\
\text { choose the business to finance. }\end{array}$} \\
\hline & - $\quad$ be $\geq 12$ months old & & \\
\hline & have legal headquarters in Italy & & \\
\hline & - have at least one financial statement & & \\
\hline & available & & \multirow{2}{*}{$\begin{array}{l}\text { All the information about the } \\
\text { applicant are published online, } \\
\text { in advance }\end{array}$} \\
\hline & - $\quad$ turnover $\geq 50,000$ Euros & & \\
\hline & $\begin{array}{l}\text { No insolvencies must be pending on the } \\
\text { company, its owners, or its representatives }\end{array}$ & & \\
\hline
\end{tabular}

The amounts loaned as at June 2018 are outlined in Table 12. As further proof of TheSocialLender's young age, data related to it do not refer to the successfully concluded campaigns, but to those in progress. Therefore, there is not certitude about the reported values and sometimes they are not available $(\mathrm{Na})$.

The greatest amount of campaigns is that of Borsadel Credito with respect to Lendix (482 versus 40). The same occurs in terms of sums loaned, equal to 38 million of Euros for Bordsdel Credito and 19.5 million of Euros for Lendix. The average loan granted by Borsadel Credito amounts to 40,000 Euros, the average expiry of loans granted was about 28 months, and average annual nominal interest rate was $5.27 \%$. The protected fund depends upon the applicants, who pay a specific warrantee commission. Finally, Borsadel Credito offers a commitment unknown to Lendix: it directly funds a minimum percentage of the projects $(51 \%)$, making the offer more credible and projects more easily feasible. 
Table 12. The amounts

\begin{tabular}{llll}
\hline \multirow{2}{*}{ Lending company } & \multicolumn{2}{l}{ Concluded campaigns } & In progress \\
& BorsadelCredito & Lendix & TheSocialLender \\
\hline $\mathrm{N}^{\circ}$ of loans & 482 & 40 & 6 \\
$\mathrm{~N}^{\circ}$ lenders & 1,144 & 456 & $\mathrm{Na}$ \\
Loan value (Euros) & $37,701,000$ & $19,583,000$ & $1,335,000$ \\
Average loan (in Euros) & 40,000 & $30,000-3,500,000$ & $30,000-3,000,000$ \\
Loan expiry date & $1-60$ months & $3-84$ months & $12-60$ months \\
Annual nominal interest rate & $3.4 \%-7.4 \%$ & $4.45 \%-9.5 \%$ & $\mathrm{Na}$ \\
Commission charged to applicant: & Yes & No & Yes \\
- $\quad$ warrantee commission & $0.4 \%-9.0 \%$ & - & - \\
$-\quad \quad$ application fees & $2.0 \%-4.0 \%$ & - & - \\
$\quad$ & & & $5 \%$ for loans $<500,000$ Euros \\
$\quad \quad$ success fee & & - & $3.5 \%$ for 500,000 Euros $\leq$ loans $\leq 1,000,000$ Euros \\
& & & $1.5 \%$ for loans $>1,000,000$ Euros \\
\hline
\end{tabular}

\section{Conclusions}

Currently 8,894 innovative start-ups (data updated as at March $31^{\text {st }}$ 2018) are registered on the Italian company register. Moreover, statistics processed on the basis of data collected by the company register highlight an issue common to all innovative start-ups, regardless of their sector, related to the degree of financial independence. Oppositely to what has been hypothesized by supporters of the so-called "financial growth cycle" (Berger and Udell, 1998) - according to whom the resources available to a start-up (in particular an innovative start-up) follow a financial hierarchy which establishes that funding in the form of equity must have the priority over resort to bank indebtedness, in that the former is less expensive and more suitable for the purpose - the Italian situation shows how start-ups severely struggle to reach a suitable amount of equity. The financial independence indicator, calculated as a ratio of assets funded through equity, shows that start-ups have a similar financial structure to that of existing joint-stock companies (respectively a 0.35 versus a 0.38 indicator, 2015 data), which by nature rely mainly on debt capital. The peculiarity of the Italian situation may be explained by the opportunity - offered by the Decree for Growth 2.0 to innovative start-ups - to have a simplified, free, and direct access to the FGPMI. By doing this, though, lawmakers have favoured the development of a leverage-based Italian start-up system, with all the related criticalities that such type of financial structure implies for business initiatives in their launch phase.

Given the above, what are the resources Italian start-ups may draw from to guarantee themselves a suitable amount of equity representing a solid financial base to launch their new business?

Upon having illustrated in simple terms the most suitable funding sources to satisfy the requirements of start-ups, following the financial growth cycle approach, this article has focused on the opportunities offered by crowdfunding platforms available online. Crowdfunding represents an innovative fund collection tool, ruled (within the limits of equity-related factors) by EU legislation and, on a national level, by CONSOB. As highlighted upon processing available data collected by the related observatories, crowdfunding is certainly growing at a fast pace. To complete the analysis, we have also performed a census of active lending crowdfunding operators in Italy. The sector shows much room for improvement, considering that only three of the platforms are purposely designed for businesses. Nevertheless - as previously underlined - peer-to-peer lending does not seem to be suitable to satisfy the hunger start-ups show for "patient capital", although according to certain experts the leverage-based Italian start-up system may become a winning model in the future (Econopoly, 2017).

\section{Acknowledgments}

Although the article is the result of an equal joint effort by the two authors, their primary individual contributions are reflected in the following sections of the article: Marina Damilano sections 3, 5 and Cristina Rovera 1,2, 4 .

\section{References}

Agrawal, A. K., Catalini, C., \& Goldfarb, A. (2011). The geography of crowdfunding. Working Paper 16820. Retrieved from https://www.researchgate.net/publication/228234410_The_Geography_of_Crowdfunding

Bartolomei, G., \& Marcozzi, A. (2015). Come finanziare una start up innovative. EPC Editor. 
Belleflamme, P., Lambert, T., \& Schwienbacher, A. (2014). Crowdfunding: Tapping the right crowd. Journal of Business Venturing, 29(5), 585-609. Retrieved from http://ssrn.com/abstract $=1578175$

Berger, A. N., \& Udell, G. F. (1998). The Economics of Small Business Finance: The Roles of Private Equity and Debt Markets in the Financial Growth Cycle. Journal of Banking \& Finance, 22(6-8), 613-673. https://doi.org/10.1016/S0378-4266(98)00038-7

Borello, G., De Crescenzo, V., \& Pichler, F. (2014). Le piattaforme di Financial return crowdfunding nell'Unione europea. Bancaria, 12, 77-90.

Brusa, L. (2016). Business Plan. Guida per imprese sane, start-up e aziende in crisi. Egea.

Cassar, G. (2004). The financing of business start-ups. Journal of Business Venturing, 19, $261-283$. https://doi.org/10.1016/s0883-9026(03)00029-6_

Chioda, E. (2016). Startup. Sogna, credici, realizza. Dall'idea al successo. Hoepli.

Coocheo, S. (2013). Crowdfinance: Banks' Friend or Foe? ABA Banking Journal, 105(10), 1-5. Retrieved from

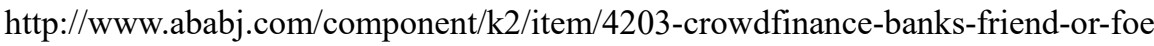

Costanza, M. (2017). Crowdfunding a lifeline for struggling startups. Rochester Business Journal, 32(48), 27.

Di Pietro, F., Prencipe, A., \& Majchrzak, A. (2018). Crowd Equity Investors: An Underutilized Asset for Open Innovation in Startups. California Management Review, 60(2), 43-70. https://doi.org/10.1177/0008125617738260

Econopoly. (2017). Startup a debito, lo strano caso delle banche che investono più dei fondi. Il Sole-24 Ore, 25th September 2017.

Giudici, G., Nava, R., Rossi Lamastra, C., \& Verecondo, C. (2012). Crowdfunding: The New Frontier for Financing Entrepreneurship? Working Paper. Retrieved from http://ssrn.com/abstract=2157429

Joachim, H. (2011). A snapshot on crowdfunding. Working Paper R2/2011. Retrieved from http://hdl.handle.net/10419/52302

Kim, K., \& Hann, I. (2013). Does Crowdfunding Democratize Access to Capital? A Geographical Analysis. Working Paper.

Kuppuswamy, V., \& Bayus, B. L. (2015). Crowdfunding creative ideas: the dynamics of profect backers in kickstarter. Working Paper. A shorter version of this paper is in The Economics of Crowdfunding: Startups, Portals, and Investor Behavior. L. Hornuf and D. Cumming (eds.), 2017. Retrieved from https://ssrn.com/abstract=2234765 or http://dx.doi.org/10.2139/ssrn.2234765

Lawton, K., \& Marom, D. (2013). The Crowdfunding Revolution: How to Raise Venture Capital Using Social Media. McGraw Hill.

Ley, A., \& Weaven, S. (2011). Exploring agency dynamics of crowdfunding in start-up capital financing Academy of Entrepreneurship Journal, 17(1), 85-110.

Massolution, Crowdfunding Industry Report (2015).

Mollick, E. (2014). The dynamics of crowdfunding: An exploratory study. Journal of Business Venturing, 29 , 1-16. http://dx.doi.org/10.1016/j.jbusvent.2013.06.005

Nadotti, L. (2014). Progettazione e finanziamento delle imprese startup. Isedi.

Nanda, R., \& Rhodes-Kropf, M. (2013). Investment cycles and startup innovation. Journal of Financial Economics, 110, 403-418. http://dx.doi.org/10.1016/j.jfineco.2013.07.001

Pagamici, B. (2015). Start up innovativa. Wolters Kluwer.

Paschen, J. (2017). Choose wisely: Crowdfunding through the stages of the startup life cycle. Business Horizons, 60(2), 179-188. https://doi.org/10.1016/j.bushor.2016.11.003

Piattelli, U. (2013). Il crowdfunding in Italia. Giappichelli Editore.

Politecnico di Milano (2016, 2017, 2018). 1, 2 e 3 Report italiano sul crowdinvesting. Retrieved from http://www.osservatoriocrowdinvesting.it/

Previati, D., Galloppo, G., \& Salustri, A. (2015). The "wisdom of crowds" as an antidote to the credit crunch: A preliminary analysis of crowdfunding. Chapter 2 in Palgrave Macmillan. Studies in Banking and Financial Institutions. Lending, Investments and the Financial Crisis, 22-51. 
Querci, F. (2014). Il crowdfunding e l'innovazione nel finanziamento delle aziende. Bancaria, 10, 26-40.

Rovera C. (2016). Banche italiane e piattaforme crowd. Impresa Progetto, 2, 1-26. Retrieved from https://www.impresaprogetto.it/essays/2016-2/rovera

Ruozi, R. (2014). Il crowdfunding e il finanziamento delle famiglie e delle PMI. economia\&management, 2, 109-117.

Sannajust, A., Roux, F., \& Chaibi, A. (2014). Crowdfunding In France: A New Revolution? The Journal of Applied Business Research, 30(6), 1919-1928.

Schwienbacher, A., \& Larralde, B. (2010). Crowdfunding of small entrepreneurial ventures. Book chapter in Handbook of Entrepreneurial Finance (Oxford University Press), 3-23.

Università Cattolica del Sacro Cuore (2015). Il Crowdfunding in Italia, Report 2015.

\section{Legal documents}

European Commission. (2013). Crowdfunding in the EU - Exploring the added value of potential EU action. Retrieved from http://ec.europa.eu/internal_market/

European Commission. (2014). Sfruttare il potenziale del crowdfunding nell'Unione europea.

CONSOB. (2013). Regolamento sulla raccolta di capitali di rischio da parte di start-up innovative tramite portali on-line, $\mathrm{n}^{\circ} 18592$.

CONSOB. (2016). Delibera ${ }^{\circ} 19520$.

Decree Law 18th October 2012, $\mathrm{n}^{\circ} 179$.

Decree Law 24th January 2015, $\mathrm{n}^{\circ} 3$.

Decree Law 24th April 2017, $\mathrm{n}^{\circ} 50$.

EBA. (2015). Opinion of the European Banking Authority on lending-based crowdfunding. Available on the EBA's website

ESMA. (2012). Insidie dell'investimento online. Retrieved from https://www.esma.europa.eu/document/l'esma-mette-in-guardia-gli-investitori-al-dettaglio-sulle-insidie-dell'inve stimento-online

Law 17th December 2012, $\mathrm{n}^{\circ} 221$.

Law 24th March 2015, n 33.

Law 11th December 2016, $\mathrm{n}^{\circ} 232$.

Law 21th June 2017, $n^{\circ} 96$.

\section{Notes}

Note 1. Please, find an example in Rovera (2016), that provides a detailed description of the Italian banking portals (Terzo Valore, Com-Unity and Produzioni dal Basso).

Note 2. Decree-Law n ${ }^{\circ}$ 179/2012 has introduced the "innovative start-up" category in our legislation, including specific bonuses and incentives for companies (and investors in such companies) demonstrating a high technological level of innovation. The innovative start-up policy has been strengthened more than once in the years following, with Decree-Law n ${ }^{\circ}$ 76/2013 (Job Decree), Decree-Law n ${ }^{\circ} 3 / 2015$ (Investment Compact), Law n ${ }^{\circ}$ 232/2016 (2017 preliminary law for approval of government budget), and most recently the 2017 Government Budget and the multi-year projections for the 2017-2019 triennium (2017 approved law for government budget) have refined, boosted, and widened the range of incentives initially included in the Decree for Growth 2.0.

Companies that may access incentives designed for "innovative start-ups" include joint-stock companies, not listed on any regulated market or any multilateral trade negotiation system, respecting the following requirements:

- Are newly founded, or in any case founded within the past 5 years;

- Have their main headquarters in Italy, another EU country, or in countries agreeing to the European Economic Area, as long as they own a production facility or branch in Italy;

- Present an annual turnover of less than 5 million Euros;

- Do not transfer or have transferred profits; 
- Have as their exclusive or primary business purpose the development, production, and commercialization of high-tech innovative products or services;

- Have not been created as the result of merger, demerger, or following the sale of a company or company branch;

- The innovative nature of the company is attested upon confirmation of at least one of the following three criteria:

a) A sum equal to $15 \%$ of the higher value between turnover and annual costs is allocated to research and development activity;

b) The total workforce includes at least $1 / 3 \mathrm{PhD}$ candidates, $\mathrm{PhDs}$, or researchers, and at least $2 / 3$ associates or co-operators to any extent must own a Master's degree;

c) The company owns, has registered or licensed a patent (industrial property), or owns registered software.

In order to benefit of the related incentives, innovative start-ups must register in the special section of the Italian company register, deposited at the Chamber of Commerce.

Note 3. See: Italian company registry, Innovative start-ups, 1st trimester 2018, table 11.

Note 4. The FGPMI is a state fund that facilitates access to credit for innovative start-ups by means of a guarantee equal to $80 \%$ of the funding amount loaned by a bank (up to a maximum of 2.5 million Euros).

Note 5. Figure 1 and Table 5 are realized by C. Rovera. The tables and graphs that follow are a re-worked version (in some cases a mix) of more than one source; for this reason the single sources are not quoted. The origin of the data is in any case always indicated in the commenting text.

Note 6. Or, in alternative, debt or peer-to-peer crowdfunding.

Note 7 . One of such categories is royalty crowdfunding, which is reward-based as a function of turnover across a given time period.

Note 8. The Italian securities and exchange commission.

Note 9. Business angels invest equity in newborn companies with strong growth potential (i.e. start-ups). The amount invested is not collected from third parties but is comprised of personal funds held by investors.

Note 10. The compound annual growth rate is the mean annual growth rate of an investment over a specified period of time longer than one year.

Note 11. The data are calculated excluding the investment vehicles and the Walliance campaigns.

Note 12. Testo Unico Bancario, $n^{\circ} 385$ issued on September $1^{\text {st }} 1993$.

\section{Copyrights}

Copyright for this article is retained by the author(s), with first publication rights granted to the journal.

This is an open-access article distributed under the terms and conditions of the Creative Commons Attribution license (http://creativecommons.org/licenses/by/4.0/). 